\title{
Diagnostic value of quantitative SPECT/CT in assessing active sacroiliitis in patients with axial spondylarthritis and/or inflammatory low back pain
}

\section{Valor diagnóstico de la SPECT/TAC cuantitativa en la evaluación de la sacroilitis activa de pacientes con espondilartritis axial y/o dolor lumbar inflamatorio}

\author{
E. Ornilla ${ }^{1}$, L. Sancho ${ }^{2}$, C. Beorlegui ${ }^{3}$, M.J. Ribelles ${ }^{2}$, D. Aquerreta ${ }^{4}$, E. Prieto ${ }^{2}$, J.M. Bondia ${ }^{4}$, \\ M.J. Cuadrado ${ }^{1}$, J.Á. Richter ${ }^{2}$
}

\begin{abstract}
Background. The diagnostic accuracy of bone scintigraphy (BS) increases with SPECT/CT imaging. It would therefore be appropriate to reassess the diagnostic utility of scintigraphy in sacroiliitis with axial spondyloarthritis (SpA). The aim of this study was to compare the diagnostic performance of MRI, SPECT/CT and a combination of both techniques in sacroiliitis, and to evaluate the correlation between quantitative SPECT/CT indices and quantitative MRI inflammatory lesion scores.

Methods. Thirty-one patients with active SpA and 22 patients with inflammatory low back pain underwent MRI and SPECT/ CT of the sacroiliac joints. The diagnostic accuracy of both techniques was calculated using clinical diagnosis as the gold standard. The correlation between MRI and SPECT/CT was calculated by comparing the SPECT/CT activity indices and the Berlin/ SPARCC scoring systems for MRI.

Results. The sensitivity and specificity values in quantitative SPECT/CT, taking the sacroiliac/promontory ratio of $>1.36$ as the cut-off value, were close to those from MRI published in the literature. The combination of both techniques increased sensitivity while maintaining high specificity. There was a moderate correlation between SPECT/CT and MRI total scores. This correlation was improved by using solely the MRI inflammation scores.

Conclusion. Quantitative SPECT/CT showed better diagnostic accuracy than planar scintigraphy and showed a moderate correlation with MRI scores in active sacroiliitis. The combination of both tests increased the diagnostic accuracy. Quantitative SPECT/CT could play a relevant role in the diagnosis of active sacroiliitis in patients with high a suspicion of SpA and a negative/inconclusive MRI test or in patients with whom MRI studies cannot be carried out.
\end{abstract}

Keywords. Diagnoses. Sacroiliitis. Spondyloarthritis. Bone scintigraphy. Magnetic resonance imaging.

\section{RESUMEN}

Fundamento. La precisión diagnóstica de la gammagrafía ósea (GO) aumenta con las imágenes SPECT/TAC haciendo conveniente reevaluar su utilidad diagnóstica en la sacroilitis de la espondiloartritis axial (EA). El objetivo fue comparar el rendimiento diagnóstico de la resonancia magnética (RM), la SPECT/TC y ambas pruebas combinadas, y evaluar la correlación entre los índices cuantitativos de ambas técnicas.

Métodos. A 31 pacientes con EA activa y 22 con lumbalgia inflamatoria se les realizó una RM y una SPECT/TC de las articulaciones sacroilíacas y se calculó la precisión diagnóstica de ambas técnicas respecto al diagnóstico clínico. La correlación entre ambas pruebas se calculó comparando los índices de actividad del SPECT/TC con los sistemas de puntuación Berlín y SPARCC de RM.

Resultados. Los valores de sensibilidad y especificidad de la SPECT/TC cuantitativa, tomando como punto de corte el cociente sacroilíaca/promontorio $>1,36$, fueron similares a los publicados para la RM. La combinación de ambas técnicas aumentó la sensibilidad manteniendo una alta especificidad. La correlación entre las escalas totales de RM y SPECT/TC fue moderada y mejoraba al utilizar únicamente las escalas de inflamación.

Conclusiones. La SPECT/TC cuantitativa muestra una mejor precisión diagnóstica que la GO planar en la sacroilitis activa y una correlación moderada con las puntuaciones de RM. La combinación de ambas técnicas aumenta la precisión diagnóstica. Por tanto, la SPECT/TAC cuantitativa podría tener un papel relevante en el diagnóstico de sacroilitis en pacientes con alta sospecha de EA y RM negativa/no concluyente o en aquellos pacientes en los que no se pueda realizar una RM.

Palabras clave. Diagnóstico. Sacroilitis. Espondiloartritis. Gammagrafía. Resonancia magnética.
1. Servicio de Reumatología. Clínica Universidad de Navarra. Pamplona. España.

2. Servicio de Medicina Nuclear. Clínica Universidad de Navarra. Pamplona. España.

3. Departamento de Salud del Gobierno de Navarra. Servicio de Planificación, Evaluación y Gestión del Conocimiento. Pamplona. España.

4. Servicio de Radiología. Clínica Universidad de Navarra. Pamplona. España.

\author{
Corresponding author: \\ Enrique Ornilla Laraudogoitia \\ Servicio de Reumatología \\ Clínica Universidad de Navarra \\ Avenida Pío XII, 36 \\ 31008 Pamplona \\ España \\ E-mail: eornilla@unav.es
}

Received: 22/01/2021 • Reviewed: 02/02/2021 • Accepted: 20/02/2021 


\section{INTRODUCTION}

Axial spondyloarthritis (SpA) is a chronic inflammatory disease with an estimated prevalence of around 0.2 to $1.2 \%^{1,2}$. It typically begins in the third decade of life, with inflammatory back pain, peripheral arthritis and enthesitis as its main clinical characteristics ${ }^{3}$. The sacroiliac joints are the most commonly affected joints, and sacroiliitis is a part of all SpA classification criteria currently used $^{4}$. Despite being a relatively common disease, there is an average diagnostic delay of eight years from the onset of symptoms ${ }^{5}$.

Over the last ten years, magnetic resonance imaging (MRI) has been regarded as the gold standard technique for the detection of acute injuries to the sacroiliac joints and spine ${ }^{5-10}$. However, it has certain limitations: it has low sensitivity in the initial stages of the disease ( $54 \%$ ) and only $30 \%$ of patients with low back pain (LBP) present signs of sacroiliitis ${ }^{11,12}$; only a few centers have rapid access to MRI with the required technical characteristics and not all SpA patients can undergo MRI, for reasons such as claustrophobia, pacemakers, vascular prostheses, etc. The Assessment of the SpondyloArthritis international Society (ASAS) criteria use bone marrow oedema (BME) as a diagnostic criterion to define active sacroiliitis ${ }^{4}$, but the lack of specificity of this sign in low-grade sacroiliitis has shifted the focus of research in recent years towards structural lesions ${ }^{13,14}$.

On the other hand, bone scintigraphy (BS) is a technique that has demonstrated its efficacy in the detection of subclinical peripheral arthritis ${ }^{15}$, making it possible to state the disease activity in SpA patients in routine clinical practice. However, the role of BS in detecting sacroiliitis in SpA patients has historically been more controversial ${ }^{16,17}$. In 2008 , a systematic review by Song et al stated that BS does not seem to be useful in the early diagnosis of patients with suspected sacroiliitis after finding sensitivity, specificity and positive predictive values of 64.9, 50.5 and 1.3, respectively ${ }^{18}$.

The incorporation of hybrid single photon emission computed tomography (SPECT/CT) has helped to address one of the major disadvantages of BS: the lack of anatomical resolution of planar images. Thanks to the SPECT/CT images, we can now exclude all elements that interfere in the quantification of counts in the regions of interest (ROIs), thus improving the sensitivity and specificity of the exploration, both qualitatively and semi-quantitatively ${ }^{19-22}$. In the specific case of sacroiliac joints, this advantage is especially relevant because, given their anatomical location, they are very difficult to evaluate in a planar image, which generates an inter-observer bias based on the accuracy of the location of the ROIs. In contrast, when using SPECT/CT images to define anatomical contours, ROIs can be accurately drawn. Two other advantages of SPECT/ CT images are the possibility of obtaining three-dimensional counts indices by volumetric analysis of the joint using volumes of interest (VOIs) and the improvement of the SPECT image quality when using the CT component for the correction of SPECT attenuation. Furthermore, CT images allow us to distinguish chronic changes in the joint such as erosions, sclerosis and ankylosis.

Despite all these advantages, the evaluation of the usefulness of SPECT/CT in the diagnosis of sacroiliitis in patients with active SpA and inflammatory LBP has not been fully addressed ${ }^{23,24}$.

The objective of this study is therefore to compare both the diagnostic performance and the quantitative parameters of SPECT/CT with those of MRI, and to evaluate the combination of both techniques for the diagnosis of sacroiliitis.

\section{METHODS}

In this prospective study, outpatients with chronic inflammatory low back pain and disease onset before 45 years of age who attended the Rheumatology clinic of our hospital (Clínica Universidad de Navarra, Pamplona, Spain) within a period of six years were recruited. The study was approved by the ethics committee of the hospital.

All patients met the new ASAS classification criteria for SpA or inflammatory low back pain (LBP) without meeting the criteria for axial spondyloarthritis ${ }^{10}$. The disease had to be clinically active at the time of inclusion. Active disease was defined as a Bath ankylosing spondylitis disease activity index (BASDAI) $\geq 4$ and/or low lumbar pain $\geq 4$ measured by the visual analog scale (VAS). The diagnosis of SpA and LBP was based on the judgment of the rheumatologist who attended the patient in the consultation.

The following demographic and clinical variables were collected from all patients: age (years), sex, symptoms duration (months), Schöber test 
(cm), visual analog scale for low back pain (VAS), Bath ankylosing spondylitis disease activity index (BASDAI), $C$ reactive protein CRP $(\mathrm{mg} / \mathrm{dL})$ and erytrocyte sedimention grade (ESG).

SPECT/CT and MRI imaging procedures were performed within two weeks of the medical visit.

SPECT/CT protocol. The ${ }^{99 \mathrm{~m} T c-H D P}$ (hydroxydiphosphonate labeled with ${ }^{99 \mathrm{~m}} \mathrm{Tc}$ ) radiopharmaceutical was administered intravenously at a dose of $1000 \mathrm{~Bq} / \mathrm{Kg}$. Planar image was systematically performed two hours after the radiopharmaceutical injection. Anterior and posterior planar images of the whole body were acquired with the patient in the supine position, using a double-head gamma camera (Siemens Symbia T2) with a low-energy, high-resolution collimator, an energy window of $140 \pm 10.5 \mathrm{KeV}$ and $256 \times 1024$ acquisition matrix, being the scanning speed of $12 \mathrm{~cm} / \mathrm{min}$. Once the planar image was completed, the SPECT/CT study of the lumbosacral area was systematically performed. The SPECT was performed with a $128 \times 128$ matrix, using both detectors, obtaining 90 images (7 seconds/image). Noncontrast CT was acquired immediately after the SPECT with the patient in the same position (130 images were obtained with a thickness of $3 \mathrm{~mm}, 110 \mathrm{mAs}$ and $130 \mathrm{Kv}$ ) to use the bone window for image evaluation.
Quantitative analysis was carried out by analysing VOIs in various regions of sacroiliac joints to obtain the counts for each region. These ROIs were selected from the left and right iliac bones and the sacral promontory. Furthermore, since the inferior pole of the sacroiliac joints is more active during inflammatory processes, ROIs were also drawn there. The quantification of the maximum value in each ROI was calculated from the VOIs counts of the total sacroiliac joint with respect to the sacral promontory (total S/P index) and of the inferior sacroiliac joint with respect to the sacral promontory (inferior S/P index) (Fig. 1). Two Nuclear Medicine specialists evaluated the SPECT/CT images, performing a systematic reading of the joints from front to back. When assessing the image, the normal qualitative pattern in SPECT/CT was defined as the absence of hypercapitant uptake foci between both sacroiliac joints and a homogeneous increase in uptake, symmetrical to that of the bone marrow. The qualitative pathological pattern on SPECT/CT was defined as the presence of asymmetric hypercapitant foci when compared to the iliac blade or the lumbar spine ${ }^{17}$. The quantitative pathological pattern on SPECT/CT was defined as any uptake of the sacroiliac joint that exceeded the best cut-off point of the receptor operating characteristic (ROC) curve.

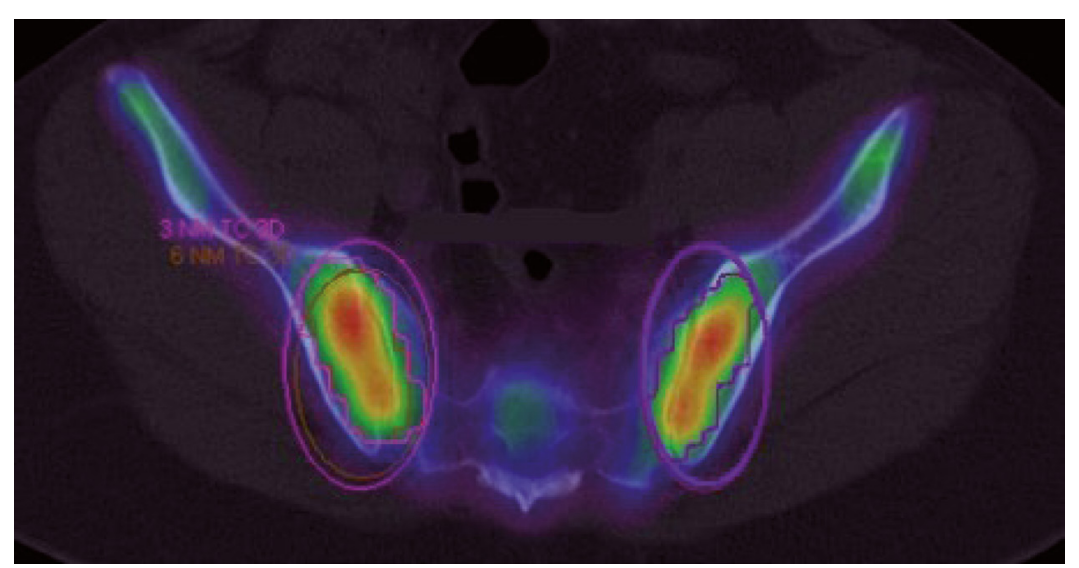

Figure 1. SPECT/CT. Bilateral sacroiliitis. Red colour indicates inflammation.

$R M$ protocol. The MRI devices used for this study were Magneton Symphony, Magneton Aera and Magneton Skyra (Siemens Healthineers). Coronal $\mathrm{T} 1$ and STIR sequences angled parallel to the sacroiliac joint and $\mathrm{T} 2$ sequences in the axial plane were included. The scanned parameters for all sequences were as follows: 20 slices, $4-5 \mathrm{~mm}$ thick per slice,
$0.4 \mathrm{~mm}$ gap between slices and a $300-400 \mathrm{~mm}$ field of view. The parameters for the $\mathrm{T} 1$ sequence were: 1,240 msec repetition time, $15 \mathrm{msec}$ echo time, echo train 3 distance and matrix $226 \times 512$ pixels. For the STIR sequence, the parameters were: repetition time 5,000 msec, inversion time $130 \mathrm{msec}$, echo time $25 \mathrm{msec}$, echo train distance 7 and matrix 218 
$-256 \times 256$ pixels. The parameters for the transverse T2 sequence were as follows: $3680 \mathrm{msec}$ repetition time, $84 \mathrm{msec}$ echo time, echo train 5 distance, and matrix 216x100 pixels. These are the scanner sequences and parameters that are routinely used for pelvic MRI scanning in patients with SpA at our institution. Contrast was not administered.

Two radiologists evaluated the MRI images with systematic front-to-back reading. Standardised definitions of lesions, and the diagnosis of active sacroiliitis on MRI were adopted based on the new ASAS classification criteria ${ }^{4}$. In order to quantify active inflammatory lesions, we used the two most commonly used MRI scores in SpA clinical trials: the Berlin score and the Spondyloarthritis Research Consortium of Canada (SPARCC) score ${ }^{25}$.

The studied variables were described by mean and standard deviation (SD) or median and interquartile range (IQR) if quantitative, and by frequency and percentage if qualitative. Inflammatory activity was measured in both groups (axial SpA and inflammatory low back pain) with MRI and SPECT/ CT. The diagnostic performance of both techniques was studied by calculating the sensitivity, specificity, and positive and negative predictive values that, in the case of SPECT/CT, were obtained from the ROC analysis. Furthermore, the area under the curve (AUC) and its 95\% confidence interval (95\% CI) were obtained for the quantitative indices of SPECT/CT and MRI.

Comparison between quantitative indices was made by Fisher's test and Mann-Whitney's U. The correlation between the MRI and SPECT/CT indices was calculated using the Sperman's rho correlation coefficient between the maximum SPECT/CT S/P index (total and inferior) and Berlin and SPARCC MRI total scores (which measure medular edema lesions along with fatty lesions, erosions, ankylosis and sclerosis lesions) and inflammation scores (which only measure medular edema lesions).

\section{RESULTS}

A cohort of 53 patients was recruited, 31 (58\%) with $\mathrm{SpA}$ and 22 with inflammatory low back pain. Both groups were similar in terms of demographic and clinical characteristics (Table 1) except for greater low back pain measured by VAS and erythrocyte sedimentation grade in SpA patients. HLA B27 was positive in $80 \%$ of the patients in the SpA group.

Table 1. Clinical and demographic characteristics of the patients

\begin{tabular}{l|c|c|c}
\cline { 2 - 3 } & \multicolumn{2}{c}{ SpA (n=31) } & LBP (n=22) \\
\hline Age (years) $^{\mathrm{a}}$ & $37.7(10.9)$ & $39.1(7.7)$ & $0.628^{\mathrm{d}}$ \\
Symptoms (months) & $48(24-102)$ & $26(18-72)$ & $0.402^{\mathrm{e}}$ \\
Sex (male) & $17(54.8 \%)$ & $9(40.9 \%)$ & $0.406^{\mathrm{f}}$ \\
HLA B27 +c $^{\mathrm{c}}$ & $25(80.6 \%)$ & 0 & - \\
VAS $^{\mathrm{b}}$ & $6(4-7)$ & $4(4-5)$ & $0.040^{\mathrm{e}}$ \\
BASDAI $^{\mathrm{a}}$ & $40.4(31.9)$ & $44.8(23.3)$ & $0.487^{\mathrm{e}}$ \\
${\text { CRP }(\mathrm{mg} / \mathrm{dL})^{\mathrm{b}}}$ & $0.17(0.076-0.60)$ & $0.11(0.064-0.727)$ & $0.372^{\mathrm{e}}$ \\
ESG $^{\mathrm{b}}$ & $10(3-12.5)$ & $3.5(2-10)$ & $0.074^{\mathrm{e}}$ \\
${\text { Schöber }(\mathrm{cm})^{\mathrm{b}}}^{\mathrm{y}}$ & $4(3-4.25)$ & $3.75(3-4)$ & $0.362^{\mathrm{e}}$ \\
\hline
\end{tabular}

SpA: Spondyloarthritis; LBP: low back pain; VAS: visual analog scale for low back pain; BASDAI: Bath ankylosing spondylitis disease activity index; CRP: C reactive protein; ESG: erytrocyte sedimention grade;

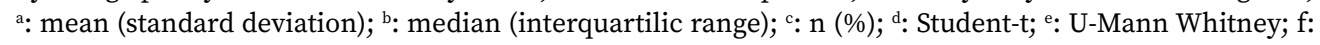
Fisher exact test.

The frequency of patients with positive results for sacroiliitis in qualitative SPECT/CT were 23 (74.2 \%) in SpA group and 13 (59.1\%) in LBP group. This yielded a sensitivity of $74.1 \%$ and a specificity of $40.9 \%$ (Table 2).
Regarding the diagnostic performance of quantitative SPECT/CT, the ROC analysis performed on the uptake of the sacroiliac joint (total S/P index) yielded an AUC value of 0.67 (95\%CI: 0.53-0.79) and an optimal cut-off point of 1.36 . This cut-off point showed 
a moderate sensitivity (51.6\%) and a high specificity (86.3\%) (Table 2). Only three patients (13.6\%) in the low back pain group obtained positive results (false positive cases). The median value of the total $\mathrm{S} / \mathrm{P}$ index was significantly lower in the low back pain group compared to the SpA group (1.12, RIC: $1.04-$ 1.31 vs. 1.36, RIC: $1.09-1.68, \mathrm{p}=0.036)$.

Positive MRI result for sacroiliitis was observed in $18(58.1 \%)$ patients in the SpA group and in no patients in the low back pain group. The ROC analysis performed using the MRI inflammation Berlin and SPARCC scores resulted in an AUC value of
0.79 (95\%CI: $0.66-0.89$ ) with a moderate sensitivity $(58.06 \%)$ and a very high specificity $(100 \%)$. ROC analysis using the MRI Berlin and SPARCC total scores resulted in an AUC value of 0.80 (95\% CI: 0.66-0.90) for the Berlin scale and 0.78 (95\%CI: 0.66-0.90) for the SPARCC scale. Again, sensitivity $(71 \%)$ and specificity $(81.8 \%)$ values were identical in both scales (Table 2).

The combination of both tests, quantitative SPECT/CT and MRI inflammation scores, improved sensitivity $(67.7 \%)$ and maintained high specificity $(86.3 \%)$ compared to individual tests.

Table 2. Diagnostic performance of SPECT/CT and MRI regarding the clinical diagnosis of axial spondylarthritis (gold standard)

\begin{tabular}{|c|c|c|c|c|}
\hline & Sensitivity & Specificity & PPV & NPV \\
\hline \multicolumn{5}{|l|}{ SPECT/CT } \\
\hline Qualitative & $\begin{array}{c}74.1 \\
(55.3-88.1)\end{array}$ & $\begin{array}{c}40.9 \\
(20.7-63.6)\end{array}$ & $\begin{array}{c}63.8 \\
(46.2-79.1)\end{array}$ & $\begin{array}{c}52.9 \\
(27.8-77)\end{array}$ \\
\hline $\begin{array}{l}\text { Quantitative } \\
\text { (cutoff }=1.36 \text { ) }\end{array}$ & $\begin{array}{c}51.6 \\
(33-69.8) \\
\end{array}$ & $\begin{array}{c}86.3 \\
(65-97) \\
\end{array}$ & $\begin{array}{c}84.2 \\
(60,4-96.6)\end{array}$ & $\begin{array}{c}55.9 \\
(37.8-72.8) \\
\end{array}$ \\
\hline \multicolumn{5}{|l|}{ MRI score } \\
\hline Inflammation & $\begin{array}{c}58 \\
(39-75.4)\end{array}$ & $\begin{array}{c}100 \\
(84.5-100)\end{array}$ & $\begin{array}{c}100 \\
(81.4-100)\end{array}$ & $\begin{array}{c}62.8 \\
(44.5-78.5)\end{array}$ \\
\hline Total & $\begin{array}{c}70.9 \\
(51.9-85.7) \\
\end{array}$ & $\begin{array}{c}81.8 \\
(59.7-94.8) \\
\end{array}$ & $\begin{array}{c}84.6 \\
(65.1-95.6) \\
\end{array}$ & $\begin{array}{c}66.6 \\
(46-83.4) \\
\end{array}$ \\
\hline \multicolumn{5}{|l|}{ MRI + SPECT/CT } \\
\hline & $\begin{array}{c}67.7 \\
(48.6-83.3)\end{array}$ & $\begin{array}{c}86.3 \\
(65-97)\end{array}$ & $\begin{array}{c}87.5 \\
(67.6-97.3)\end{array}$ & $\begin{array}{c}75.4 \\
(61.7-86.2)\end{array}$ \\
\hline
\end{tabular}

All values were accompanied by their $95 \%$ confidence intervals; PPV: positive predictive value; NPV: negative predictive value.

When we used the MRI inflammation score as gold standard for active sacroiliitis instead of clinical diagnosis, we found the following values for the quantitative SPECT/CT test: $72.22 \%$ sensitivity, $76.9 \%$ specificity, $81.3 \% \mathrm{PPV}$ and $66.7 \% \mathrm{NPV}$.

In both groups, SPECT/CT total S/P scores showed a moderate correlation with MRI total scores $($ rho $=0.51, \mathrm{p}<0.001)$ and slightly higher correlation with MRI inflammation scores $(\mathrm{rho}=0.58$ with
Berlin and rho $=0.6$ with SPARCC, both $\mathrm{p}<0.001$ ). No correlation was found with fat scores ( $\mathrm{rho}=0.14$ with Berlin and rho $=0.15$ with SPARCC) (Table 3). In the SpA group, the correlation between SPECT/ CT S/P scores and MRI total scores was higher for inferior S/P scores (0.411 vs. 0.367 , both $\mathrm{p}>0.01)$ and MRI inflammation scores $(0.668 v s .0 .602$, both $\mathrm{p}<0.001)$ scores, upgrading from medium to moderate (Table 3 ). 
Table 3. Correlation (Spearman's rho) between SPECT/CT (total and inferior) sacroiliac/promontory indices and MRI Berlin-SPARCC (total and inflammation) scores

\begin{tabular}{|c|c|c|c|c|c|c|}
\hline & \multicolumn{2}{|c|}{ Total Score } & \multicolumn{2}{|c|}{ Inflammation Score } & \multicolumn{2}{|c|}{ Fat Score } \\
\hline & Berlin & SPARCC & Berlin & SPARCC & Berlin & SPARCC \\
\hline \multicolumn{7}{|l|}{ All patients } \\
\hline $\begin{array}{l}\mathrm{S} / \mathrm{P} \text { total } \\
\mathrm{p} \text {-value }\end{array}$ & $\begin{array}{c}0.505 \\
<0.001 \\
\end{array}$ & $\begin{array}{c}0.509 \\
<0.001 \\
\end{array}$ & $\begin{array}{c}0.582 \\
<0.001\end{array}$ & $\begin{array}{c}0.596 \\
<0.001 \\
\end{array}$ & $\begin{array}{l}0.143 \\
0.307 \\
\end{array}$ & $\begin{array}{l}0.154 \\
0.270 \\
\end{array}$ \\
\hline \multicolumn{7}{|l|}{ SpA patients } \\
\hline $\begin{array}{l}\mathrm{S} / \mathrm{P} \text { total } \\
\mathrm{p} \text {-value }\end{array}$ & $\begin{array}{l}0.367 \\
0.042\end{array}$ & $\begin{array}{l}0.380 \\
0.035\end{array}$ & $\begin{array}{c}0.602 \\
<0.001\end{array}$ & $\begin{array}{c}0.634 \\
<0.001\end{array}$ & & \\
\hline $\begin{array}{l}\mathrm{S} / \mathrm{P} \text { inferior } \\
\mathrm{p} \text {-value }\end{array}$ & $\begin{array}{l}0.411 \\
0.022\end{array}$ & $\begin{array}{l}0.403 \\
0.024\end{array}$ & $\begin{array}{c}0.668 \\
<0.001\end{array}$ & $\begin{array}{c}0.657 \\
<0.001\end{array}$ & & \\
\hline
\end{tabular}

$\mathrm{S} / \mathrm{P}$ total: total sacroiliac/promontory index; S/P inferior: inferior sacroiliac/promontory index.

\section{DISCUSSION}

The demographic characteristics of this study group, with a mean age of 38 years, predominantly male and $80 \%$ of HLA B27 positive cases, are similar to other SpA cohort studies published in the literature ${ }^{1,2,7,12}$.

The main objective of our study was to analyze the role of quantitative SPECT/CT, quantitative MRI and their combination in the diagnosis of active sacroiliitis.

Quantitative SPECT/CT yielded, for a cut-off value of 1.36 , a sensitivity of $52 \%$ and a specificity of $86 \%$. These values differ from the three studies published in the literature that compare quantitative SPECT/CT and MRI in active SpA sacroiliitis (although none of them use quantitative MRI scales). Kim et $\mathrm{al}^{26}$ found that, for a cut-off value of 1.5 , the sensitivity and specificity values of the quantitative SPECT/CT were $90 \%$ and $80 \%$, respectively. The differences with our study are due to the different cut-off values used and the fact that Kim et al compared SpA patients to healthy subjects rather than to inflammatory low back pain patients. In the second study, Cui et $\mathrm{al}^{27}$ found that, with a cut-off value of 1.34, the quantitative SPECT/CT test had a sensitivity of $92 \%$ and a specificity of $62 \%$. The use of histological sacroiliitis as the gold standard instead of clinical diagnosis would probably explain these differences. Undoubtedly, histological sacroiliitis is the best possible gold standard, but its high cost and the risks it poses for the patient make it difficult to perform. The third study by Parghane et $\mathrm{al}^{28}$ used MRI rather than clinical diagnosis as the gold standard. They studied $155 \mathrm{SpA}$ patients without a control group and found that, for a cutoff value of $>1$, the sensitivity and specificity values of the quantitative SPECT/CT were $90 \%$ and $80 \%$, respectively. Again, the differences with our study ( $72 \%$ sensitivity, $77 \%$ specificity) may be due to the different cut-off values used.

Given that we were trying to discriminate between patients with inflammatory low back pain and patients with active SpA, a test with high specificity and good diagnostic precision was required. This first condition was supported by the gain in specificity achieved when quantitative SPECT/CT was used instead of a qualitative test (86 vs. $41 \%$ ). However, if we compare the SPECT/CT data of our study with the bone planar scintigraphy results from a systematic review by Song et $\mathrm{al}^{18}$, we observe a mild loss in sensitivity ( $65 v$ v. $52 \%$ ) with a significant increase in specificity (50 vs. $86 \%$ ).

If we analyze the role of MRI in the diagnosis of active sacroiliitis through the data obtained from the MRI inflammation scores (58\% sensitivity and $100 \%$ specificity), the results were slightly better than those described in the literature $(51 \%$ and $97 \%)^{4}$, highlighting the fact that chronic lesions interfere with the MRI results.

The use of a combination of MRI and SPECT/CT resulted in a gain in sensitivity with a slight loss of specificity with respect to the MRI values (67 vs. $58 \%$ sensitivity; 86 vs. $100 \%$ specificity). Consequently, six of the thirteen patients (40\%) with clinically diagnosed SpA and negative MRI became 
positive, confirming the clinical suspicion of active sacroiliitis.

Thanks to the MRI indices, we were able to verify that chronic injuries in sacroiliac joints (fat, erosion and ankylosis lesions) are much less susceptible to being captured by the SPECT/CT test than inflammatory lesions, reinforcing the hypothesis that the SPECT/CT test should be used in patients with non-chronic stages of SpA. However, when we tried to see if the study of the lower area of the sacroiliac joints, where the main inflammation in SpA patients occurs, was better than the study of the total joint area, we did not find any significant differences between both indices. We were also unable to find a correlation between higher SPECT/CT uptake and higher MRI scores. This is probably due in both cases to the high number of low-grade positive values among the MRI positive tests of our SpA patients.

In conclusion, the results of our study show that quantitative SPECT/CT has a similar sensitivity and a slightly lower specificity than MRI for the diagnosis of active sacroiliitis in SpA patients, with a significant increase in specificity with respect to planar BS. Furthermore, the combination of both techniques brings about a notable increase in sensitivity while maintaining a specificity close to $90 \%$, making for a reduction in a false negative of the MRI. There was a moderate correlation between SPECT/ CT and MRI for the measurement of active sacroiliitis. This correlation improves with the use of quantitative SPECT/CT (SI/PM index 21.36 ) and the MRI inflammation scales that rule out chronic lesions (fat, sclerosis, ankylosis and erosive lesions). Due to the small study sample, we were unable to confirm the correlation between the MRI inflammation scales and the SPECT/CT uptake index, which would increase the diagnostic/prognostic value of SPECT/CT and help the clinician make therapeutic decisions.

While we hope to confirm these findings with larger sample size studies, we believe that quantitative SPECT/CT could play a relevant role in the diagnosis of active sacroiliitis in patients with inflammatory low back pain with high suspicion of SpA and a negative/inconclusive MRI test or in patients on whom MRI studies cannot be performed.

\section{Conflicts of interest}

Carmen Beorlegui belongs to the editorial board of this journal and declares not to have influenced reviewers selection and decision making; moreover, peer-review process was double-blinded. The rest of the authors declare that they have no conflicts of interest to disclose.

\section{Funding}

This research received no external funding.

\section{Acknowledgement}

Not applicable.

\section{REFERENCES}

1. Gran JT, Husby G, HordVIK M. Prevalence of ankylosing spondylitis in males and females in a young middle-aged population of Tromso, Northern Norway. Ann Rheum Dis 1985; 44: 359-367. https://doi.org/10.1136/ ard.44.6.359

2. Braun J, Bollow M, Remlinger G, Eggens U, RudWALEIT M, DistLer A et al. Prevalence of spondylarthropathies in HLA-B27 positive and negative blood donors. Arthritis Rheum 1998; 41: 58-67. https://doi.org/10 .1002/1529-0131(199801)41:1<58::aid-art8>3.0.c0;2-g

3. GARRIDO-CUMBrera M, NAVARRo-COMpÁN V, ZARCo P, COLLANTES-EstÉvez E, GÁLVEZ-RUIZ D et al. Atlas of axial spondyloarthritis in Spain 2017: study design and population. Reumatol Clin 2019; 15: 127-132. https://doi. org/10.1016/j.reumae.2018.09.010

4. Rudwaleit M, JuRiK AG, Hermann K-GA, Landewé R, VAN DER HEIJDE D, BARALIAKOS X et al. Defining active sacroiliitis on magnetic resonance imaging (MRI) for classification of axial spondyloarthritis: a consensual approach by the ASAS/OMERACT MRI group Ann Rheum Dis 2009; 68: 1520-1527. http://dx.doi. org/10.1136/ard.2009.110767

5. SChuller-Weiderkamm C, Mascarenas V, SUDOŁ-SZOPIOSKa I, Boutry N, Plagou A, Kaluser A et al. Imaging and interpretation of axial spondyloarthritis: the radiologist's perspective - consensus of the Arthritis Subcommittee of the ESSR. Semin Muskuloskelet Radiol 2014; 18: 265-279. https://doi.org/10.1055/s-0034-1375569

6. SANZ SANZ J. [Role of MRI in the diagnosis and progression of spondyloarthritis.] Reumatol Clin 2012; 8: 37S-41S. https://doi.org/10.1016/j.reuma.2011.12.002

7. Weber U, Lambert RG, Østergaard M, Hodler J, Pedersen SJ, MaKsymowych WP. The diagnostic utility of magnetic resonance imaging in spondylarthritis: an international multicenter evaluation of one hundred eighty-seven subjects. Arthritis Rheum 2010; 62: 30483058. https://doi.org/10.1002/art.27571

8. Uson J, LOZA E, MÖller I, ACEBES C, ANDREU JL, BATLLE $\mathrm{E}$ et al. Recommendations for the use of ultrasound 
and magnetic resonance in patients with spondyloarthritis, including psoriatic arthritis, and patients with juvenile idiopathic arthritis. Reumatol Clin 2018; 14: 2735. https://doi.org/10.1016/j.reumae.2016.08.007

9. Narváez JA, Bueno Horcajadas A, DE Miguel MenDIETA E, SANZ SANZ J. Guidelines for magnetic resonance imaging in axial spondyloarthritis: A Delphi study. Radiología 2015; 57: 512-522. https://doi.org/10.1016/j. rxeng.2015.09.006

10. Rudwaleit M, van deR Heijde D, Landewé R, LisTING J, AKKOC N, BRANDT J et al. The development of Assessment of SpondyloArthritis international Society classification criteria for axial spondyloarthritis (part II): validation and final selection. Ann Rheum Dis 2009; 68: 777-783. https://doi.org/10.1136/ard.2009.108233corr1

11. WEBER U, MAKSYMOWYCH WP. Advances and challenges in spondyloarthritis imaging for diagnosis and assessment of disease. Curr Rheumatol Rep 2013; 15: 345. https://doi.org/10.1007/s11926-013-0345-Z

12. ARnbak B, JURIK AG, HøRSLEV-PETERSEN K, HENDRICKS O, HERMANSEN LT, LOFT AG et al. Associations between spondyloarthritis and MRI findings: a cross-sectional analysis of 1020 patients with persistent low back pain. Arthritis Rheum 2016; 68: 892-900. https://doi. org/10.1002/art.39551

13. WEBER U, ØStERgaARd M, LAMBERT RGW, PEDERSEN SJ, Chan SM, Zubler V et al. Candidate lesion-based criteria for defining a positive sacroiliac joint MRI in two cohorts of patients with axial spondyloarthritis. Ann Rheum Dis 2015; 74: 1976-1982. https://doi.org/10.1136/ annrheumdis-2014-205408

14. LAMbert RGW, BAKKeR PAC, VAN DER HeIJDE D, WeBER U, RUdWALEIT M, HeRmann KGA et al. Defining active sacroiliitis on MRI for classification of axial spondyloarthritis: update by the ASAS MRI working group. Ann Rheum Dis 2016; 75: 1958-1963. https://doi. org/10.1136/annrheumdis-2015-208642

15. BRAUN J, SIEPER J, BOLLOW M. Imaging of sacroiliitis. Clin Rheumatol 2000; 19: 51-57. https://doi.org/10.1007/ s100670050011

16. Goldberg RP, Genant HK, SHimshaK R, SHAmes D. Applications and limitations of quantitative sacroiliac joint scintigraphy. Radiology 1978; 128: 683-686. https:// doi.org/10.1148/128.3.683

17. PEH WCG, Ho WY, LUK KDK. Applications of bone scintigraphy in ankylosing spondylitis. Clinical Imaging 1997; 21: 54-62. https://doi.org/10.1016/0899-7071(95)00065-8

18. SONG IH, CARRASCo-FERnÁNDEZ J, RUdWALEIT M, SIPER J. The diagnostic value of scintigraphy in assessing sacroiliitis in ankylosing spondylitis: a systematic lite- rature research. Ann Rheum Dis 2008; 67: 1535-1540. https://doi.org/10.1136/ard.2007.083089

19. UTSUNOMIYA D, SHIRAISHI S, IMUTA M, TOMIGUCHI S, KAWANAKA K, MORISHITA S et al. Added value of SPECT/ CT fusion in assessing suspected bone metastasis: comparison with scintigraphy alone and nonfused scintigraphy and CT. Radiology 2006; 238: 264-271. https://doi. org/10.1148/radiol.2373041358

20. Zhang Y, Shi H, Gu Y, XiU Y, Li B, ZHU W et al. Differential diagnostic value of single-photon emission computed tomography/spiral computed tomography with Tc-99m-methylene diphosphonate in patients with spinal lesions. Nucl Med Commun 2011; 3: 1194-1200. https://doi.org/10.1097/mnm.0b013e32834bd82e

21. Linke R, KUWERT T, UdER M, FORST R, WUEST W. Skeletal SPECT/CT of the peripheral extremities. AJR Am J Roentgenol 2010; 194: W329-W335. https://doi. org/10.2214/ajr.09.3288

22. KlaESER B, SPANJOl M, KRAUSE T. SPECT/CT diagnostics for skeletal infections. Radiologe 2012; 52: 615-620. https://doi.org/10.1007/s00117-011-2272-1

23. Koç ZP, KIn CENGIZ A, Aydin F, SAMANCi N, YAZISIZ V, KocA SS et al. Sacroiliac indicis increase the specificity of bone scintigraphy in the diagnosis of sacroiliitis. Mol Imaging Radionucl Ther 2015; 24: 8-14. https://doi. org/10.4274/mirt.40427

24. Strobel K, Burger C, Seifert B, Husarik DB, SOYKa JD, HANY TF. Characterization of focal bone lesions in the axial skeleton: performance of planar bone scintigraphy compared with SPECT and SPECT fused with CT. AJR Am J Roentgenol 2007; 188: W467-W474. https://doi. org/10.2214/ajr.06.1215

25. ASAS/OMERACT MRI in AS Working Group. Is there a preferred method for scoring activity of the spine by magnetic resonance imaging in ankylosing spondylitis? J Rheumatol. 2007; 34: 871-873.

26. KIM YI, SUH M, KIM YK, LEE HY, SHIN K. The usefulness of bone SPECT/CT imaging with volume of interest analysis in early axial spondyloarthritis. BMC Musculoskelet Disord 2015; 16: 9. https://doi.org/10.1186/ s12891-015-0465-X

27. CUI Y, ZHANG X, ZHAO Z, LIU Y, ZHENG J. The relationship between histopathological and imaging features of sacroiliitis. Int J Clin Exp Med 2015; 8: 5904-5910.

28. Parghane R, Singh B, Sharma A, Singh H, Singh P, BHATTACHARYA A. Role of 99mTc-Methylene diphosphonate SPECT/CT in the detection of sacroiliitis in patients with spondyloarthropathy: comparison with clinical markers and MRI. J Nucl Med Technol 2017; 45: 280-284. https://doi.org/10.2967/jnmt.117.193094 